\title{
Mule Drivers in Nineteenth-Century Lebanon: from local social history towards Global History
}

DOl: http://dx.doi.org/10.1590/2236-463320161403

Joane Chaker

History Department of Harvard University, Cambridge - MA, Estados Unidos da América joanechaker@g.harvard.edu

Abstract: This article makes the case for a project in the making: a study of the social transformation of the countryside as it joins the global market over the long nineteenth century, told as a collective biography of the mule drivers of Ottoman Lebanon - those obscure peasants who, owning one or a few mules, made their livelihood in the transport of goods and persons rather than work the land. Over the first half of the century, these actors mobilized for revolts while a village-based economy turned to cash-crop agriculture and the central government built a new state apparatus that would insure its survival within global capitalism, rendering the peasants' situation ever more precarious. From the 1860s to the First World War, as local resources were diverted to feed European industry and local petty-trade networks came undone, when elites at all levels struggled to assert their control over labor and resources, these same muleteers turned into social bandits smugglers who defended the peasant against the state's taxation and the capitalists' extraction. Some of them accumulated wealth and ultimately integrated an emerging middle class. The projected account makes two historiographical interventions. (a) Within the history of the modern Middle East, it argues that the region's confessional tensions are tied to developments that are characteristic of capitalism over the period - namely, the rise of a new kind of state and the loss of control over resources by local actors at the margins. This approach pushes against purely culturalist explanations, attempting to wed culturalist and materialist stances. (b) Conversely, by drawing parallels with other mounted 
rural bandits in the Anatolian and Romanian hinterlands of the Ottoman Empire, as well as with the gauchos in Latin America, ox-cart drivers in India, and rickshaw pullers in China, this local history speaks to a global history of capitalism. Reducing the scale of analysis to reveal the subjectivity of local actors, and linking the cultural norms that shape agency to objective structural transformation that can be compared across contexts, this project challenges histories of capitalism that ignore the countryside or the global South and thereby produce a sanitized account characterized by secular politics and a liberal culture.

Keywords: Global history; Rural history; Social history; Peasant revolt; Subaltern; Capitalism; Ottoman Empire; Middle East; Lebanon; Sectarianism; the Novel (literary genre); Nineteenth century.

\section{Introduction}

This article makes the case for a project in the making: a study of the social transformation of the countryside as it joins the global market over the long nineteenth century, told as a collective biography of the mule drivers of Ottoman Lebanon - those obscure peasants who, owning one or a few mules, made their livelihood in the transport of goods and persons rather than work the land. Over the first half of the century, these actors mobilized for revolts while a village-based economy turned to cash-crop agriculture and the central government built a new state apparatus that would insure its survival within global capitalism, rendering the peasants' situation ever more precarious. From the 1860s to the First World War, as local resources were diverted to feed European industry and local petty-trade networks came undone, when elites at all levels struggled to assert their control over labor and resources, these same muleteers turned into social bandits smugglers who defended the peasant against the state's taxation and the capitalists' extraction. Some of them accumulated wealth and ultimately integrated an emerging middle class.

The projected account makes two historiographical interventions. (a) Within the history of the modern Middle East, it argues that the region's confessional tensions are tied to developments that are characteristic of capitalism over the period - namely, the 
rise of a new kind of state and the loss of control over resources by local actors at the margins. This approach pushes against purely culturalist explanations, attempting to wed culturalist and materialist stances. (b) Conversely, by drawing parallels with other mounted rural bandits in the Anatolian and Romanian hinterlands of the Ottoman Empire, as well as with the gauchos in Latin America, ox-cart drivers in India, and rickshaw pullers in China, this local history speaks to a global history of capitalism. Reducing the scale of analysis to reveal the subjectivity of local actors, and linking the cultural norms that shape agency to objective structural transformation that can be compared across contexts, this project challenges histories of capitalism that ignore the countryside or the global South and thereby produce a sanitized account characterized by secular politics and a liberal culture.

\section{The Turn to Cash Crop Cultivation and the Struggle Over the Control of Surplus, $1800-1860$}

Although cotton was an important factor in the commercialization of the Ottoman countryside, the empire's principal export was tobacco, which went mostly to Egypt, where it was rolled into cigarettes. The Egyptian cigarette became a sought-after article of luxury in Europe, and tobacco prices rose steadily throughout the nineteenth century. ${ }^{1}$ This soon became the richest sector in agriculture, and some regions - namely Salonika, the shores of the Adriatic and of the Black Sea, and particularly Latakia on the Syrian coast - rapidly specialized in tobacco cultivation in response to foreign demand. Tobacco was also grown in the Lebanese mountain, particularly in the area of Kura and in the southern-most parts; but the most important export of that particular region was silk. Toward the end of the eighteenth century, demand for the mountain's raw silk from the cities of the Syrian interior, from France, and from Egypt increased significantly. Maritime trade developed fast along the Syrian coast, and mulberry trees, alongside other cash crops such as vines and olives, expanded at the expense of grains and the varied products of subsistence

\footnotetext{
${ }^{1}$ Oscar Wilde attached the consumption of Egyptian cigarettes to the image of the dandy. See WELIVER, Phyllis. Oscar Wilde, Music, and the 'Opium-Tainted Cigarette': Disinterested Dandies and Critical Play. J ournal of Victorian Culture 15, 3, 2010, p. 324, 334.
} 
farming. By the early nineteenth-century, the Lebanese mountain imported up to 65 percent of its grain consumption from Egypt or the Syrian interior. ${ }^{2}$

The growing capacity of this economy to generate cash soon attracted the attention of the state and of elites at all levels, who fought for the control of this trade and the profit it generated by championing competing political projects for the region. This narrative can serve to frame the 1820 revolt by peasants in the northern Lebanese mountain refusing to pay additional taxes imposed by a new provincial governor in 'Akka; the mounting tensions among the elites themselves throughout the mountain; the expansion of the Maronite Church's land possessions and influence; and its new role as the mouthpiece of the grieved peasants of northern Lebanon. ${ }^{3}$ The biggest contender for control over the growing Syrian-Egyptian trade, however, was the separatist provincial governor of Egypt, Mehmet Ali. Ibrahim, Mehmet Ali's son, occupied Syria in 1832. Under his rule, Beirut rose to prominence among the ports of the Syrian coast, and the BeirutZahle road was opened to link the interior to the port. This expanded markets and credit to the peasants, encouraging the shift to mulberry trees, olive trees, and grapevine, as well as tobacco. Most importantly, with the spread of sericulture and demographic growth, land increased in value. This period again saw peasant rebellions, in Hawran in 1837-1838, and in the northern parts of Mount Lebanon in $1840 .{ }^{4}$

The real threat to lbrahim's project, however, was not this subaltern resistance, but the retaliation of a new Sultan in Istanbul. In 1839, Abdülmecid promulgated the Tanzimat, a regime of reforms promising fair taxation, an end to trade restrictions, security

\footnotetext{
${ }^{2}$ AKARLI, Engin Deniz. The Long Peace: Ottoman Lebanon, 1861-1920. Berkeley, Los Angeles and London: University of California Press, 1993, p. 17-8; ISSAWI, Charles (ed.). The Economic History of Turkey, 18001914. Chicago: University of Chicago Press, 1980, p. 49, 52, 250-2; -... The Economic History of the Middle East, 1800-1914. Chicago and London: The University of Chicago Press, 1966, p. 229; MURPHY, Rhoads. Tobacco Cultivation in Northern Syria and Conditions of its Marketing and Distribution in the Late Eighteenth Century. Turcica 17, 1985, p. 207-11; QUATAERT, Donald. Social Disintegration and Popular Resistance in the Ottoman Empire, 1881-1908: Reactions to European Economic Penetration. New York and London: New York University Press, 1983, p. 13; TOKSÖZ, M eltem. The Çukurova: From Nomadic Life to Commercial Agriculture, 1800-1908. Ph.D .dissertation, State University of New York at Binghamton, 2000.

${ }^{3}$ AKARLI, Engin Deniz. Op. Cit., p. 19, 21, 26.

${ }^{4}$ AKARLI, Engin Deniz. Op. Cit., p. 23-4; BUHEIRI, Marwan. The Peasant Revolt of 1858 in Mount Lebanon: Rising Expectations, Economic Malaise and the Incentive to Arm. In: KHALIDI, Tarif (ed.). Land Tenure and Social Transformation in the Middle East. Beirut: American University of Beirut, 1984, p.291; Hawran is a Druze mountainous area extending from what is today southwestern Syria into the northwestern corner of Jordan.
} 
of property and life, and the equitable treatment of all subjects before the law. The thrust of the Gülhane rescript, the Hatt- । Hümayun of 1839, and of the programmatic directive that followed it in the nizamname of 1840, was to remove the tax farmer, cast as parasitic, so that more justly assessed taxation develops the wealth of the productive households of the empire. ${ }^{5}$ While the reforms were presented as protecting the peasantry against excessive exploitation, in practice, they promised to disentangle land from the web of layered rights that prohibited its commercialization, so that it could serve as collateral. The production of cash crops for a global market necessitated credit, and credit required collateral. In that sense, the reform program announced in 1839 catered to the interests of European industrialists, creditors, and financiers who would profit from that financing and that commerce. The edict also stated: "Everything that can impede commerce or agriculture shall be abolished. To accomplish these objects means shall be sought to profit by the science, the art, and the funds of Europe." ${ }^{6}$ Thus the edict promised to open the region up to European capital. Effectively, European states, in support of their own capitalists, soon backed the Sultan: in 1841, Ibrahim was pushed back by a joint British, Austrian, and Ottoman campaign. In this account, the reforms cannot be separated from the 1838 trade conventions signed by the Ottoman state with the British, French, Russians, and Austrians, inaugurating a period of free trade.

This open-door policy gave Europeans and their local associates an advantage over other local merchants, landed notables, and artisans, who became dependent on the former for credit and business. In the Lebanese mountain, moreover, the elites who had been ousted by Ibrahim for siding with the Ottomans returned to reclaim estates they considered their own, only to be faced by peasants who refused to be considered tenants. Perceptions of proprietorship were already changing, but they were still being disputed. As the lords were Druze and the peasantry Maronite, the conflict turned into a bloody sectarian war in 1841. As a solution, and under European pressure, the central government split the region into two qaim-maqamiyyas, or districts, one formally dedicated to the

\footnotetext{
${ }^{5}$ MUNDI, M artha; SAUM AREZ Richard. Governing Property, M aking the Modern State: Law, Administration and Production in Ottoman Syria. London: I.B Tauris, 2007; p. 41, 44.

${ }^{6}$ BEININ, Joel. Workers and Farmers in the Modern Middle East. Cambridge and New York: Cambridge University Press, 2001. p. 44-5.
} 


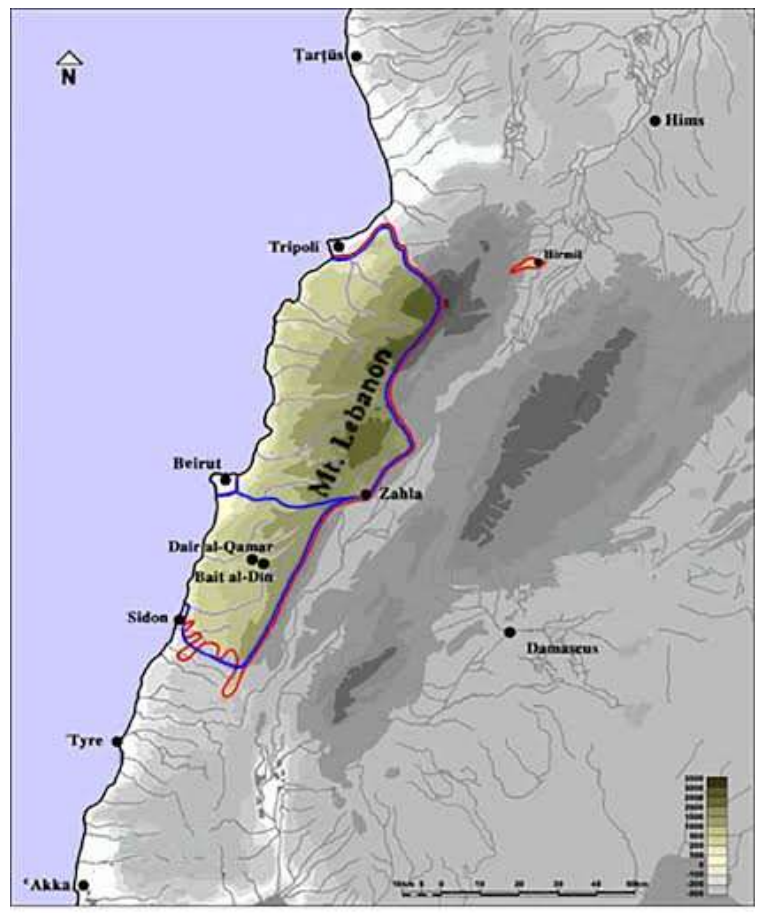

Maronites and one to the Druzes. It attempted a cadastral survey but was blocked by the elites, who fought among themselves and against the peasantry to assert control over as much land as possible. ${ }^{7}$ In Kisrawan, a region within the northern, "christian," qaim-maqamiyya, the imposition of harsh tenancy conditions led to a revolt by the peasants of Kisrawan in 1858-1859, the expulsion the local Khazin lords, and the take- over of their property. The peasants further south were soon moved by the same spirit - here however, the peasants were Maronite while the lords were Druze, and the strife turned sectarian, the European powers each intervening on behalf of a sect. This was resolved with an organic statute called the "Règlement for the Reorganization of Mount Lebanon," instituting the mutasarrifiyya ruled by a centrally appointed Christian governor in consultation with a locally elected council. Each village elected a sheikh, and those sheikhs elected the councilors. That council had the power to veto tax increases and had the prerogative of internally distributing the centrally imposed tax burden. A "rather simplistic and rudimentary" survey to count the population as well as measure and assess the value of cultivated land and income-yielding buildings, begun in 1861, was completed in 1869. This survey provided the basis for the property tax, which remained fixed until the mandate period. 8

\footnotetext{
${ }^{7}$ AKARLI, Engin Deniz. Op. Cit., p. 24-9.

${ }^{8}$ AKARLI, Engin Deniz. Op. Cit., p. 29, 106-7; CHEVALIER, Dominique. Aux origines des troubles agraires Libanais en 1858. Annales, 14, 1959, p. 44-51; PORATH, Yehoshua. The Peasant Revolt of 1858-1861 in Kisrawan. Asian and African Studies, 2, 1966, p. 77-157; BUHEIRY, Marwan. Op. Cit., p. 291-302; KERR, Malcolm (ed.). Lebanon in the Last Years of Feudalism, 1840-1860: A Contemporary Account by Antun Dahir al- 'Aqiqi and Other Documents. Beirut: American University of Beirut, 1959. p. 19-26, 95-150.
} 


\section{The Muleteers as Mutineers, 1800-1860}

Despite mentions, time and again, of muleteers standing out from the rioting crowd, their role as an important mobilizing force in the peasant revolts mentioned in the previous section has gone unnoted. Tanyos Shahin, the renowned leader of the revolt of 1858 mentioned above, was a farrier turned muleteer. ${ }^{9}$ Mansur Butrus Abu Antoine and Butrus Tannus, prominent rebels captured during the same uprising and beaten until blood "ran down their bodies as if it were water," were the muleteer of the village of Rayfun and the muleteer of the village of 'Ajaltun, respectively. ${ }^{10}$

Why were those working in rural transport more likely to lead the revolts? The answer is inspired by Hobsbawm's and Scott's article "Political Shoemakers," in which the authors note that their subjects were self-employed, mobile, in contact with large numbers of humble people, and independent from patrons, wealthy clients and employers. ${ }^{11}$ All these attributes were equally true of workers in rural transport, who owned their means of production the world over. A study of rickshaw men who led popular revolts in republican China notes that these individuals were "freer and more independent than many workers," and thus acquired a reputation for combativeness. ${ }^{12}$ Flexible and mobile, the Banjara ox-cart drivers of nineteenth-century Indian Berar were described as "hardy, frank and independent people." ${ }^{13}$ In the turn- of-the-century novel by the Lebanese author Ameen Rihani entitled The Muleteer and the Priest, the Lebanese muleteer, too, comes across as "a cheerful, direct person who does not conceal his views." 14

The Lebanese muleteer, explains the narrator of Rihani's novel, is innately intelligent because he spends most of his time in contemplative solitude, in the tranquility

${ }^{9}$ YAZBAK, Yusuf Ibrahim. Al-judhur al-tarikhiyya li al-harb al-lubnaniyya [The Historical Root Causes of the Lebanese War]. Beirut: Nawfal, 1993. p. 268.

${ }^{10}$ M AKDISI, Ussama. Corrupting the Sublime Sultanate: The Revolt of Tanyus Shahin in Nineteenth-Century Ottoman Lebanon. Comparative Studies in Society and History, v. 42, n. 1, Jan. 2000, p. 207.

${ }^{11}$ HOBSBAWM , Eric J.; SCOTT, Joan Wallach. Political Shoemakers. Past \& Present, 89, Nov. 1980, p. 103.

${ }^{12}$ STRAND, David. Rickshaw Beijing: City People and Politics in the 1920s. Berkeley, Los Angeles, and London: University of California Press, 1989. p. 61, 63.

${ }^{13}$ SATYA, Laxman D. Cotton and Famine in Berar, 1850-1900. New Delhi: Manohar, 1997. p. 247, 259.

${ }^{14}$ From the description of a translation of the novel on a German publishers' website, patmos.de/dereseltreiber-und-der-priester-p-8038.html, accessed on August 1, 2016. The original novel is: RIHANI, Ameen. Al-Mukari wa-I-Kahin [The Muleteer and the Priest]. New York: Al-Huda Printing Press, 1904. The novel was translated into German as Der Eseltreiber und der Priester by Ursula Assaf and Simon Yussuf Assaf, and appeared in three editions (Geneva: Patmos, 1996; Dusselrof and Zurich: Patmos, 2003; and Mannheim: Patmos, 2011). 
of mountains, valleys and plains. Precisely because of this solitude, one can imagine the muleteers to have been open and ready for conversation when in company. They collected many anecdotes with which they entertained their passengers. ${ }^{15}$ The muleteers met each other at the inns, where they could share the news of the day glanced while roaming different parts. Tanyos Shahin, the muleteer who led the peasant revolt of 1858, had traveled particularly widely for the times. As he often worked for the missionary school in Rayfun, the Lazarist monks had obtained for him credentials from the French consulate that allowed him to pass internal borders. ${ }^{16}$ Travel was equally important in the character construction of Abu Tannus, the muleteer in Rihani's novel, for it allowed him to reckon that poverty was not a circumstantial problem besetting a number of individuals, but a society-wide, structural issue:

Running behind my mules, roaming the mountains from the south end to the north, I realized that the rich among the people were very few, countable on the fingers of two hands. And I realized that the people, consisting of sharecroppers and muleteers and peasants, did not own anything. Where are the mountain's goods then? In whose hands are they? In whose coffers is the money accumulating? Who is eating the harvest? ${ }^{17}$

Joined through their work to the basic rhythms of rural life, rural transport workers had a privileged perspective of society at large.

More generally, travel seems to have fostered the muleteers' readiness to accept new ideas. In his continual peregrinations, the muleteer met people from all ranks and discovered many villages. ${ }^{18}$ Tanyos Shahin learned a lot from his discussions with the Lazarist missionaries as he drove them back and forth; not only could he repeat French republican ideas of social justice, but he also ended up "half-literate," and by some accounts even spoke some Italian. ${ }^{19}$ In that he resembled the rickshaw men, who were marginally literate, and knew "a smattering of foreign phrases for the tourist trade." 20 Similarly, mingling freely with people from all across the sub-continent, the Banjaras

\footnotetext{
${ }^{15}$ RIHANI, Ameen. Al-M ukari wa-I-Kahin [The Muleteer and the Priest]. Beirut: Dar al-Rihani Ii-I-Tiba'a wa-INashr, 1969. p. 8-10.

${ }^{16}$ M AKDISI, Ussama. Op. Cit., p. 194.

${ }^{17}$ RIHANI, Ameen. Al-Mukari, 1969, p. 36- 7.

${ }^{18}$ Ibidem, p. 10, 14.

${ }^{19}$ KERR, Malcolm. Op. Cit., p. 22; YAZBAK, Yusuf Ibrahim. Op. Cit., p. 268.

${ }^{20}$ STRAND, David. Op. Cit., p. 41, 57.
} 
spoke many languages and acquired the ability to communicate with very different people with equal ease..$^{21}$

More importantly, as he was likely to be his clients' creditor, the muleteer was probably linked with them by bonds of confidence, just as the Banjaras were "trustfully employed [...] by ever suspicious Indian merchants, traders, and moneylenders." 22 A person in this position "had license to express his opinions, which there was no reason to distrust." ${ }^{23}$ The muleteer or the cart driver had conversations with his numerous clients individually rather than in big groups, on the lonesome journey between villages. At the same time, he could always find an audience, and like the rickshaw pullers, had the power to spread rumors and to move individual grievances into the public realm. ${ }^{24}$ For all these reasons, he was strategically well placed to circulate ideas and perhaps even mobilize for action.

\section{Capitalist Transformation from the Perspective of the Subaltern, 1860-1914}

Land reforms and other legal innovations worked alongside technical innovations, such as railroads, to provide the European industry with vital primary materials. Yet these forces also meant the extinction of local market networks and the dying out of the local economy. Naturally, the actors to apprehend this trend first and foremost were those working in rural transport.

Speaking of Indian Berar, Satya states: "The region in pre-colonial times exhibited the vibrancy of buyers and sellers [...]. In this type of a mobile society the Banjaras were a very important factor. [...] By the time of colonial takeover the Banjaras had developed a complex network of fairs and bazars along which their carts moved." ${ }^{25}$ At every village fair and weekly Bazar in pre-colonial Berar, "the Banjara caravans came from all directions heavily laden with the needs of the populace." ${ }^{26}$ Similarly, the Lebanese muleteers exchanged the mountain's fruits and olive oil against the wheat of Hawran in the south of

${ }^{21}$ SATYA, Laxman D. Op. Cit., p. 247, 249, 252.

22 Ibidem, p. 247.

${ }^{23}$ HOBSBAWM , Eric J.; SCOTT, Joan Wallach. Op. Cit., p. 103-4.

${ }^{24}$ STRAND, David. Op. Cit., p. 63.

${ }^{25}$ SATYA, Laxman D. Op. Cit., p. 260.

${ }^{26}$ Ibidem, p. 248-9. 
modern-day Syria, and against textiles and food bought in the cities along the way. ${ }^{27}$ Throughout the latter half of the nineteenth century, however, the transport infrastructure developed quickly with the aim of opening the country to the world market. The BeirutDamascus road, linking the hinterland across the mountain range to the rapidly developing port, was completed in 1863. In place of the three-day-journey on horseback from Damascus to Beirut across the mountain, it offered a daily coach service that took a mere thirteen hours. At the turn of the century, a railroad connecting the two cities through the mountain (quite literally, by a tunnel) made the journey even shorter, and exponentially increased the transport capacity. Built and run by foreign capital, that same line extended to the grain-producing region of Hawran.28

This had been an important route for the muleteers. Modern transport not only put rural transport workers out of business. It also undid local trade networks more generally. The Damascene sheikh al- Qasimi records in his dictionary:

A very frequent trade before the railroad passed through, there used to be no less than two hundred muleteers in Damascus on any single day, or more. [...] This was very lucrative to the people, merchants, grain vendors, fodder vendors, and innkeepers. All this has come to be missed in Damascus; this trade has declined infinitely, and those who practice it have become very few in numbers, God only knows the reason why, there is no Lord but He. ${ }^{29}$

These developments parallel the ones in Berar, where "the diversity of products available at [...] fairs gave a tremendous degree of choice to the people in articles of daily consumption which became scarcer [...]." ${ }^{30}$ According to Satya:

The railway in Berar primarily transported cotton but the Banjara bullock carts carried both cotton and grains. After the demise of Banjaras the cotton was transported by European firms and moneylenders in their own carts. The grain supply became more localized as the 'old grain carriers of former years before the days of the railway' disappeared from the roads and became cultivators.

${ }^{27}$ AL-QASIMI, Muhammad Said; AL-QASIMI, Jamal al-Din; AL-'ATHM, Khalil. Qamus al- Sina'at at Shamiyya [The Dictionary of Damascene Trades]. Ed. AL-QASIMI, Thafir. Paris: M outon \& Co., 1960, p. 466.

${ }^{28}$ AKARLI, Engin Deniz. Op. Cit., p. 113-4; ISSAWI. The Economic History of the Middle East, particularly Part IV Chapter 4.

${ }^{29}$ AL-QASIMI Muhammad Said; AL-QASIM I, Jamal al-Din; AL-'ATHM, Khalii. Op. Cit., p. 466.

${ }^{30}$ SATYA, Laxman D. Op. Cit., p. 256. 
With this disappearance many small articles of daily consumption which were hitherto available to the village population were no longer available. ${ }^{31}$

In short, with the land reforms, resources in the periphery converged towards the railway system that thrust them into industrial Europe. The transition effected by the forces of supply and demand was hastened with regulation aimed at further limiting internal commerce, thereby speeding up the death of local industry. ${ }^{32}$ This story is normally told as a sequel to the forced dispossession and coerced labor effected by foreign armies, as they were in the Americas or in India. ${ }^{33}$ Bringing these diverse backgrounds into a single narrative encompassing the Ottoman Empire, where a local elite was part and parcel of the transformation, may serve to question the distinction between war capitalism and capitalism tout court.

\section{The Muleteers as Social Bandits, 1860 - 1914}

Smuggling was an effort on the part of muleteers to stay in business. Yet that same activity benefited the peasantry more broadly. Again, the bandit-muleteers have gone unnoted by historians, despite mentions in the sources of Lebanese muleteers smuggling now tobacco, then wheat, at a time when these products were controlled by monopolists or requisitioned for army provisioning.

During the famine that preceded the First World War in Lebanon, when the Turkish army was requisitioning foodstuffs, Druze muleteers in bands of fifteen to twenty undertook expeditions to the neighboring Druze mountain of Hawran, from where they smuggled back wheat. ${ }^{34}$ This was particularly vital to the peasantry when food was scarce..$^{35}$ The smuggling not only ensured survival in times of famine; more generally, it

${ }^{31}$ Ibidem, p. 264.

32 Ibidem, p. 260-1, 265- 7.

${ }^{33}$ SATYA, Laxman D. Op. Cit., Chapter 6: "Colonial Sedenterization and Subjugation: The Case of Banjaras of Berar"; BECKERT, Sven. Empire of Cotton: A Global History. New York: Alfred A. Knopf, 2015. Chapter 4: "Capturing Labor, Conquering Land." See also: DAVIS, Mike. Late Victorian Holocausts: El Niño Famines and the Making of the Third World. London: Verso, 2001.

${ }^{34}$ UNITED KINGDOM , HOUSE OF COM M ONS. Report for the Year 1886 on the Trade of Beyrout. In: Sessional Papers, 1887. London: William Clowes and Sons, for HM S0, 1806-1908. 503-10, p. 509; BRAND, Tylor. Lives Darkened by Calamity: Enduring the Famine of World War I in Lebanon and Western Syria. Ph.D. diss., American University of Beirut, 2014, p. 123-4.

35 HOBSBAWM quotes a historian of Italy to the effect that "the rhythm of hunger determined [...] the rhythm of brigandage." Bandits. New York: The New York Press, 2000, p. 10. 
perpetuated the "traditional" marketing networks delegitimized by the new. It worked against state monopolies and barriers to entry inherent in the new scale of production and marketing, thus pushing back against the proletarianization of the peasantry. In the 1880s, French and British official reports accused "Druze nomads" of massive tobacco smuggling in and out of Lebanon ${ }^{36}$ As the Druze population was entirely settled, and in view of the bands of muleteers involved in wheat smuggling, it is safe to assume that the French reporters had confused these bands of muleteers for nomads. The Ottoman Public Debt Administration estimated that a good third of tobacco consumed in the empire escaped the control of a foreign-owned tobacco Régie during the first five years of operations from 1883. ${ }^{37}$ Quataert cited more drastic figures, such as the estimate of an Ottoman employee of the Régie that "official tobacco sales of nearly 6 million kilograms compared poorly with the 12 to 13 million that were sold illegally." Years onwards, the Régie had to admit, "farmers' resistance was so powerful that it had prevented the organization from securing its operations in most areas of the empire." 38

The smuggling was as beneficial to the peasants as it was to the muleteers. The growers declared less than the surface they actually cultivated and sold the undeclared tobacco to the smugglers, at up to two or three times the Régie's price. The higher price was considered a form of rectification compensating the cultivators for the loss of income caused by Régie practices. Smuggling also spared the farmer taxes, and spared him shares to the landlord when he was a sharecropper. ${ }^{39}$ The tobacco was then secretly sold in Damascus through the tutunji (tobacco vendor), or through farram al-tatan (literally the tobacco chopper), thereby sustaining local artisans who otherwise could not compete against the exporters for their primary material. ${ }^{40}$

For these reasons, these muleteers-turned-smugglers were considered men of worth in the peasant community:

\footnotetext{
${ }^{36}$ VERNEY, Noël; DAM BM ANN George. Les Puissances Etrangères dans le Levant en Syrie et en Palestine. Paris: Guillaumin, 1900, p. 184.

${ }^{37} \mathrm{THOBIE}$, Jacques. Intérêts et Impérialisme Français dans I'Empire Ottoman (1895-1914). Paris: Imprimerie Nationale, 1977, p. 187.

${ }^{38}$ QUATAERT, Donald. Op. Cit., p. 19, 21.

39 Ibidem, p. 18-9. THOBIE, Jacques. Op. Cit., p. 187.

${ }^{40}$ AL-QASIMI M uhammad Said; AL-QASIMI, Jamal al- Din; AL- 'ATHM, Khalil. Op. Cit., p. 66, 337.
} 
The inherent risk of smuggling increased the price of the trafficked food when it was sold in the villages, but it is interesting to note that the mountain smugglers were not regarded with the same social stigma as were the speculators and merchants of the town. [...] The character of the smuggler appears in numerous memoirs and recollections of the period, more often than not in laudatory terms. To some extent, this may have been because they were seen less as parasites seeking to exploit their own people, but rather as intrepid villains cast in the mold of Robin Hood, whose aim was to deceive the hated Turks to supply their own people. ${ }^{41}$

The social aspect of the muleteers' smuggling was so unambiguous that it remains engraved today in the oral accounts of a third generation, which proudly relates these adventures as heroic deeds with an "epic quality." 42 Tanyos Shahin, the head of the revolt of 1860 , was a sort of folk hero..$^{43}$ The Protestant missionary Malcom Kerr depreciatingly described him as a "self-appointed Robin Hood" - associating him with the social bandit par excellence. ${ }^{44}$ Similarly, in colonial Berar, legendary bandits and highwaymen like Mitu Bhukia who defied state authority were worshipped as symbols of Banjara independence and protest. ${ }^{45}$

\section{Into the Twentieth Century: The Muleteers as Pragmatic Individuals}

A bandit may accumulate capital. His redistributions are often a price for refuge, arms, or protection. "Unlike other peasants, he acquires wealth and exerts power." He may secure land and merge with a new bourgeoisie. ${ }^{46}$ This view has been taken to its extreme by Anton Blok, who insisted that "we should treat brigandage and bandit myth as forces that weaken peasant mobilization." 47 In Blok's analysis, if a bandit wants to remain "social," his only protection is the peasantry, and that is certainly a weak source of protection. The bandits that survive, then, are those who place their particular interests

${ }^{41}$ BRAND, Tylor. Op. Cit., p. 157-8.

${ }^{42}$ BRAND, Tylor. Op. Cit.

${ }^{43}$ FAWWAZ, Leila. An Occasion for War: Civil Conflict in Lebanon and Damascus in 1860. Berkeley and Los Angeles: University of California Press, 1994. p. 45

${ }^{44}$ KERR, Malcolm. Op. Cit., 22.

${ }^{45}$ SATYA, Laxman D. Op. Cit., 256.

${ }^{46}$ HOBSBAWM , Eric J. Bandits, p. 95, 105, 118.

${ }^{47}$ BLOK, Anton. The Mafia of a Sicilian Village: A Study of Violent Peasant Entrepreneurs, 1860-1960. Oxford: Blackwell, 1974. p. 97-102. 
ahead of everything else. ${ }^{48}$ Effectively, the Lebanese muleteers, small-time merchants, were well placed to take advantage of the transforming economy. ${ }^{49}$ Oral accounts documenting the famine the swept through the Lebanese mountain during the First World War reveal that some muleteers accumulated wealth by smuggling, and ultimately integrated an emerging middle class. Because of his involvement in smuggling, the family of muleteer Jammul Mahmud did not suffer from the famine. The interviewee who reported this also conveyed that her maternal family, by contrast to that of her paternal grandfather Jammul Mahmud, suffered severe deprivation - despite her maternal grandfather's prestigious political position in Mount Lebanon's local governing council, majlis al-a'yan. More importantly, we also learn that Mahmud's smuggling activity allowed him to amass enough capital to buy land..$^{50}$

With time, the social structures that had supported peasant resistance changed. Inevitably, the muleteers, gauchos, and rickshaw pullers were displaced by railroads and motorcars. Yet all these characters figured in the early twentieth century as protagonists in novels. The literary genre of the Arabic novel, in itself, was the result of a tension between the two principal forces, "variously known as the old and the new, the traditional and the modern [...]; more specifically, the encounter with the West, its science and culture, on the one hand, and on the other, the rediscovery and stimulation of the great classical heritage of Arab- Islamic culture." ${ }^{51}$ While the new literary form reflected a desire to modernize, resort to the classical heritage or focus on the traditional peasantry could be read as the affirmation of an imagined identity in the face of dissolution in a globalizing world - both on the part of the author and his readers, all members of an emerging middle class. ${ }^{52}$ This was the case in nineteenth-century Argentina. As integration into the global market drew waves of immigrants to the Rio de la Plata, romanticists resorted to the

${ }^{48}$ Idem. The Peasant and the Brigand: Social Banditry Reconsidered. Comparative Studies in Society and History, 14, 1972, p. 495 - 504.

${ }^{49}$ SATYA, Laxman D. Op. Cit., p. 251.

${ }^{50}$ BRAND, Tylor. Op. Cit., p. 110, 124.

${ }^{51}$ ALLEN, Roger. The Arabic Novel: An Historical and Critical Introduction. New York: Syracuse University Press, 1995, p. 11-2.

${ }^{52}$ For a linking between the emergence of the novel as a literary form and the formation of a middle class, see: BENJ AM IN, Walter. The Storyteller. In: HALE, Dorothy J. (ed.). The Novel: An Anthology of Criticism and Theory 1900-2000. Malden: Blackwell Publishing, 2006, p. 365. 
figure of the gaucho to affirm a national identity. ${ }^{53}$ Similarly, in China, writers and poets often featured rickshaw-men as central characters - so often that one can refer to "rickshaw works" as a literary genre, dealing with themes ranging from the mysteries of life to the nature of capitalism. ${ }^{54}$ Within the confines of what was the Ottoman Empire, the banditeering cattle drovers known as the Hajduks made it into the novels of Panait Istrati; ${ }^{55}$ Anatolian bandit lore is perpetuated to this day in the horseman Mehmed, the hero of Yaşar Kemal's best-selling novel, inspired by stories Kemal heard from bandits seeking refuge in his village; ${ }^{56}$ and the Lebanese muleteer made an appearance in the novel of Ameen Rihani.

To borrow Walter Benjamin's stirring prose: "The birthplace of the novel is the solitary individual." ${ }^{57}$ The actors involved in rural transport effectively witnessed firsthand the dissolution of community. Their reappearance in the burgeoning literary genre of the novel gives their story an epilogue, and their historian a sense of the visceral angst that accompanied the crossover into modern liberalism.

\section{Theoretical Stakes: On the Ottoman Rural Context - Is it Capitalism?}

As detailed in the first section of this article, during the first six decades of the nineteenth century, a series of popular uprisings racked the Lebanese countryside. These events were initially explained in terms of religious intolerance to the modernizing Ottoman reforms, particularly to the introduction of the category of citizenship, which

\footnotetext{
${ }^{53}$ FERRERAS, Norberto 0. Bandoleiros, cangaceiros e matreiros: revisão da historiografia sobre o Banditismo Social na América Latina. História, 22, 2, 2003. Accessed online at http://dx.doi.org/10.1590/S010190742003000200012 on August 1, 2016.

${ }^{54}$ STRAND, David. Op. Cit., p. 21, 23.

${ }^{55}$ The Hungarian word hajtók or hajdók means "cattle drovers." These elements later integrated the Hungarian infantry referred to by the Ottomans as Hajduks, and the word came to signify the outlaws, brigands, and highwaymen romanticized in the folkloric tradition of Southeastern Europe as freedom fighters. See www.familytreedna.com/public/hajdu, accessed on January 9, 2016.

${ }^{56} \mathrm{BIRCH}$, Nicholas. Yaşar Kemal's Disappearing World of Stories. The Guardian, November 28, 2008. Accessed online at http://www.theguardian.com/books/2008/nov/28/yasar-kemal, on January 9,2016 . The novel in question is Ince Memed, or Memed, My Hawk (1955), and the same hero featured in subsequent novels by the same author.

${ }^{57}$ BENJ AMIN, Walter. Op. Cit., p. 364.
} 
limited the right of confessional minorities to self-management. ${ }^{58} \mathrm{~A}$ nationalist historiography later pointed to the manipulation of the various confessional denominations against each other by European or Ottoman interests for the sake of geopolitics - suggesting an otherwise-homogeneous Lebanese society. ${ }^{59}$ Economic developments and the attending social transformation only moved center stage with the advent of British-style economic-history and the French Annales school to Lebanese historiography. Both approaches relied on macroeconomic analysis and quantitative data to highlight that other aspect of the Ottoman modernizing reforms: the region's incorporation into the global market, with the attending transformations in land-tenure, prices, and relations of production. ${ }^{60}$

Against this background of structural economic transformation, some historians resorted to the categories of political economy, drawing comparisons between the Lebanese revolt of 1858 and the German Bauernkrieg of $1525 .{ }^{61}$ However, they became entangled in the debates associated with that approach: could one speak of class when the peasants were backing the elites on both sides of a confessional war? ${ }^{62}$ Overall,

${ }^{58}$ For instance, MAOZ, Moshe. Communal Conflicts in Ottoman Syria during the Reform Era: The Role of Political and Economic Factors. In: BRAUDE Benjamin; LEWIS, Bernard (eds.). Christians and Jews in the Ottoman Empire: The Functioning of a Plural Society. New York: Holmes and Meier, 1982, p. 91- 105.

${ }^{59}$ For example, NUJAIM, Bulos (M. Jouplain). La Question du Liban: Etude d'histoire diplomatique et de droit international. Paris: Librairie Nouvelle de Droit et de Jurisprudence, 1908.

${ }^{60}$ CHEVALIER, Dominique. La société du Mont Liban à l'époque de la révolution industrielle en Europe. Paris: University of Chicago Press, 1971; _... Aux origines des troubles agraires libanais. In: ISSAWI, Charles (ed.). The Economic History of the Midd̄le East; OWEN, Roger. The Silk-Reeling Industry of Mount Lebanon, 1840-1914: A Study of the Possibilities and Limitations of Factory Production in the Periphery. In: ISLAM OGLU-INAN, Huri (ed.). The Ottoman Empire and the World Economy. New York: Cambridge University Press, 2004, p. 270-3; WEULERSSE, Jacques. Paysans de la Syrie et du Proche Orient. Paris: Gallimard, 1946. Part of the series "Le paysan et la terre," founded by Marc Bloch.

${ }^{61}$ BAER, Gabriel. Fellah and Townsman in the Middle East: Studies in Social History. New York: Frank Cass and Company Limited, 1982, p. 272, 278.

${ }^{62}$ Compare SM ILIANSKAYA, I. M. "The Disintegration of Feudal Relations in Syria and Lebanon in the Middle of the Nineteenth Century" re-titled "From Subsistence to Market Economy, 1850s" in a reprint, in: ISSAWI, Charles (ed.). The Economic History of the Middle East; and BUHEIRI, Marwan. Op. Cit., particularly p. 291. Related to this debate is the question of whether the system of land holding in the Lebanese mountain can be referred to as feudal. Placing the local landholding system of iqta' somewhere in between Ottoman iltizam and thirteenth-century European feudalism, some historians of Lebanon claimed a special status for the region within the Ottoman Empire, and described the local chieftains as "quasi-feudal." More recent literature, however, shows that Lebanon until the eighteenth century was more similar to the rest of the empire, the assumption of difference actually relying on a teleological account constructed with the later nineteenth-century context in mind. See AKARLI, Engin Deniz. Op. Cit., p. 27 n. 50. This debate is summarized in SCHÖLCH, Alexander. Was There a Feudal System in Ottoman Lebanon and Palestine? In: KUSHNER, David (ed.). Palestine in the Late Ottoman Period. Jerusalem and Leiden, 1986, p. 130- 45. 
economic and confessional identities did not map onto each other. This is generally true of the global South, and postcolonial theory justly resists the reduction "of diverse experiences of oppression and marginalization to the single axis of class." 63 In line with this tendency, a more recent Lebanese historiography abandoned the categories of political economy in favor of discourse analysis. The events of 1858 are thus explained by Ussama Makdisi as popular religious mobilization against a rigid nonsectarian social hierarchy "expressed as the rule of knowledge over ignorance." In this view, the mobilization reflects a subaltern understanding of Ottoman modernization. ${ }^{64}$

Culture and ideology have an abiding role in shaping history; however, the effort to avoid economic reductionism often ends up paying too little attention to material conditions. The approach proposed in this article weds the culturalist and materialist stances by showing how the muleteers' militancy was tied to the material conditions of their trade. Being engaged in transport between village and town, muleteers spoke to people from all walks of life. They were well informed and exposed to the ideas of a wider world. Perpetual witnesses joined through their work to the pulse of the rural economy, they had a privileged perspective of society at large. In addition, their independence from a landlord, their ownership of their means of production, and their organic connection to peasant society made them plausible spokesmen. For all these reasons, they were strategically well placed to circulate ideas and even mobilize for action. Rather than work with an exacting definition of class, reducing the scale of analysis to a history of the muleteer sheds light on the mentalities that led people to see certain uses of land, price movements, or market arrangements as just or unjust. It brings out logic behind the lines of social solidarity that cannot be apprehended only in light of confessional loyalties or solely in terms of class analysis. ${ }^{65}$

\footnotetext{
${ }^{63}$ CHAKRABARTY, Dipesh. Provincializing Europe: Postcolonial Thought and Historical Difference. Princeton: Princeton University Press, 2007, p. 48; Views from the South, 1, 2000, p. 26. Subaltern Studies and Postcolonial Historiography. Neplanta:

${ }^{64} \mathrm{M}$ AKDISI, Ussama. Op. Cit., p. 181-3.

${ }^{65}$ Some of the models here are the works of Eric Hobsbawm and E. P. Thompson cited throughout this article.
} 


\section{Theoretical Stakes: What is Capitalism? A Perspective from the Ottoman Countryside.}

The perpetuation of the hierarchies and culture of the ancien régime in the global South - in Ranajit Guha's famous phrase, "dominance without hegemony" - contrasted fundamentally with the rising importance of modern citizenship and secular politics in the West. ${ }^{66}$ Subaltern Studies read this as capitalism's failure to take root in the postcolonial world. ${ }^{67}$ In pushback, a global history approach insists that ethnic, religious, and communal discourses might very well be perpetuated by the dynamics of capitalism, as long as they serve to strengthen an elite's hold over labor, resources, and markets. In this view, what is common across the various contexts - and an important characteristic of capitalism - is a strengthening of the state. Capitalism required the mobilization of resources on a new scale. Capitalists in Western Europe created powerful states that expanded their markets and lent them support in their ventures abroad. Elites in the periphery soon followed, building states that would defend their markets and support them in that competition. ${ }^{68}$

In this context, the Crimean War of 1850s is one of a series of wars that inaugurate a period of military competition on an unprecedented scale between states of a new kind. ${ }^{69}$ To cover this expenditure and repay its foreign debt, the Ottoman government invested in infrastructure that reached deep into the countryside, tightened fiscal control, and created monopolies on tobacco, salt, and other commodities. When European financiers came to control Ottoman state revenues through the Public Debt Administration in the 1880s, centralization only intensified, and more so with the nationalist revolution of 1908. Throughout these events, local elites at varying levels adopted different discourses for the purpose of popular mobilization in the face of more distant capitalists - be they in Istanbul or in one of Europe's financial centers. This framework could at once explain

\footnotetext{
${ }^{66}$ Hegemony is defined as reliance on consent rather than coercion. See GUHA, Ranajit. Dominance Without Hegemony: History and Power in Colonial India. Cambridge and London: Harvard University Press, 1998; . On Some Aspects of the Historiography of Colonial India. In: on South Asian History \& Society. Delhi: Oxford University Press, 1982, p. 43.

${ }^{67}$ CHAKRABARTY, Dipesh. Subaltern Studies and Postcolonial Historiography, 15, 20; CHATTERJEE, Partha. The Nation and its Peasants. In: (ed.) The Nation and its Fragments: Colonial and Postcolonial Histories. Princeton: Princeton University Press, 1993, p. 165.

${ }^{68}$ BECKERT, Sven. Op. Cit., p. xv, 313-6, 396; CHIBBER, Vivek. Postcolonial Theory and the Specter of Capital. London, New York: Verso, 2013, p. 24-6; 78-9; M AIER, Charles. Leviathan 2.0: Inventing Modern Statehood. Cambridge and London: The Belknap Press of Harvard University Press, 2012.

${ }^{69}$ M AlER, Charles. Op. Cit., p. 20, 22.
} 
Lebanese or Arab nationalisms as well as Pan-Islamism. ${ }^{70}$ It could equally explain more parochial and regional confessional tensions as constituents of a history of capitalism. Nonetheless, because it is told from the perspective of the elite, this account remains divorced from subaltern political psychology. It does not address what Guha refers to as the subaltern domain, autonomous, he insists, because "it neither originated from elite politics nor did its existence depend on the latter." ${ }^{71}$

A history of rural transport workers is niched in this gap: it is a description of the dynamics of capitalism as perceived by the subaltern. Legal innovations such as land reforms, and technological improvements such as railroads, the hallmarks of the capitalist transition, are most often thought of as processes that make markets. Paving the way for direct taxation and commercial credit, they open the countryside to global capital and tie it into the global market. What this picture leaves out is the local economy that comes undone when resources in the periphery are diverted for the benefit of global capital. Necessarily, the actors working in rural transport felt firsthand the local petty-trade networks coming undone. Rural societies expressed their opposition by participating in, or at least acquiescing to, smuggling. By smuggling, these muleteers worked to preserve a local economy weakened by state policies and the barriers to entry inherent in the new scales of production and marketing. They also fought against a new precariousness that arose when the diversity of articles of the peasants' daily consumption gradually became unavailable. For this reason, these muleteers turned smugglers were considered men of worth in the peasant community - local Robin Hoods, so to speak, in line with the social bandits that Hobsbawm found in all traditional rural societies resisting the incursion of the state into the countryside. ${ }^{72}$

\section{Conclusion}

Where a global history of capitalism may pass over parochial political psychology, and while a postcolonial history privileges local culture in the confines of the fragment,

\footnotetext{
${ }^{70}$ In their competition against powerful capitalists, "the new entrepreneurs were forced to build coalitions with increasingly mobilized [...] groups of workers and peasants within their own societies." See BECKERT, Sven. Op. Cit., p. 417-8.

${ }^{71} \mathrm{GUHA}$, Ranajit. On Some Aspects of the Historiography of Colonial India, p. 39-42.

${ }^{72}$ HOBSBAWM, Eric J. Bandits. New York: The New York Press, 2000, p. 7, 9.
} 
the muleteers' story holds both particularity and resonance. The particularity gives the reader a sense of the palpable life behind the history; the resonance makes the history relevant to a wider theoretical context. By showing how the muleteer's militancy was tied to the material conditions of his trade and to his economic relationships, this historical narrative links the cultural norms that shape agency to objective structural transformation that can be compared across contexts. The Lebanese muleteers engaging in banditry and organizing revolt have an echo in the horseman and mule driver Emiliano Zapata. They have an echo in the Balkan confines of the Ottoman Empire in the Hajduks; and they have an echo in the horseman Mehmed, the hero of Yaşar Kemal's novels. Further away, in Indian Berar, the Banjara ox-cart drivers engaged in smuggling were hailed by the peasantry as social bandits; and in China, the rickshaw pullers took the leading role in mobilizing for revolt. ${ }^{73}$ The transition to capitalism unfolded very differently in all these contexts. Land reform in Indian Berar, for instance, meant a swift equalization and homogenization in land tenure, and a brutal transfer of power from local elites to the colonial government..$^{74}$ In the Ottoman Empire, the reforms intended to unify practice were negotiated at the level of the district and in every village between representatives of the central administration, a regional elite, and actors in productive systems on the ground, who shaped different outcomes in different local political economies. ${ }^{75}$ In some areas, peasants became small landowners. In others, they turned into tenants to tribal leaders and townsmen on lands they had formerly cultivated for their own. ${ }^{76}$ Despite these differences in the establishment of a wide variety of property-right regimes, the repertoire of actions developed by peasant societies at this historical juncture remains very similar. The implication is that despite the differences in the transition to capitalism, this moment of history can still be apprehended in terms of a unique dynamic operating on a global scale - economic pressures, which these agents, by the nature of their trade, perceived and acted on ahead of others.

${ }^{73}$ SATYA, Laxman D. Op. Cit., p. 253, 256, 271. STRAND, David. Op. Cit., p. 21, 23.

${ }^{74}$ SATYA, Laxman D. Op. Cit., p. 55-63, 84-5.

${ }^{75} \mathrm{MUNDI}$, Martha; SAUM AREZ Richard. Op. Cit., p. 3, 7.

${ }^{76}$ FIRRO, Kais. Silk and Agrarian Changes in Lebanon, 1860-1914. International Journal of Middle East Studies v. 22, n. 2, May 1990, p. 157, 160-4; IRBY, Joseph K. Aspects of Musha' Land Tenure in Lebanon. Yearbook of the Association of Pacific Coast Geographers, 33, 1971, p. 158; M UNDI, Martha; SAUM AREZ Richard. Op. Cit., p. 6, 47, 101-2, 235. 
A history of the muleteers brings material conditions back in without, however, denying the principal role of culture in shaping agency. A journey into the everyday world of these nameless individuals can focus the complex intersections between the politicalcultural history of confessional identities and the socio-economic transformations attending integration into the global market. It strives towards the history E. P. Thompson called for, that of "plebeian and patrician and a great deal of what lies in between: commerce, manufacture, [...] overseas empire." ${ }^{77}$ And from this vantage point, social and cultural history on a small scale can cross over into global history.

Data de recebimento do artigo: 26/08/2016

Deta de aprovação db artigo: 23/10/2016

\section{Bibliography}

AKARLI, Engin Deniz. The Long Peace: Ottoman Lebanon, 1861-1920. Berkeley: Los Angeles, London: University of California Press, 1993.

AL-QASIMI, Muhammad Said, Jamal al-Din al-Qasimi, and Khalil al-'Athm. Qamus alSina'at at-Shamiyya [The Dictionary of Damascene Trades]. Ed. Thafir al-Qasimi. Paris: M outon \& Co., 1960.

ALLEN, Roger. The Arabic Novel: An Historical and Critical Introduction. New York: Syracuse University Press, 1995.

BAER, Gabriel. Fellah and Townsman in the Middle East: Studies in Social History. New York: Frank Cass and Company Limited, 1982.

BECKERT, Sven. Empire of Cotton: A Global History. New York: Alfred A. Knopf, 2015.

BEININ, Joel. Workers and Farmers in the Modern Middle East. Cambridge and New York: Cambridge University Press, 2001.

${ }_{77}^{7 H}$ THM PSON, E. P. Customs in Common: Studies in Traditional Popular Culture. New York: New Press, 1991, p. 17. 
BENJAM IN, Walter. "The Storyteller." In: HALE, Dorothy J. (ed.), The Novel: An Anthology of Criticism and Theory 1900-2000. Malden: Blackwell Publishing, 2006, p. 361-78.

BIRCH, Nicholas. Yaşar Kemal's Disappearing World of Stories. The Guardian, November 28, 2008. Accessed online at http://www.theguardian.com/books/2008/nov/28/yasarkemal, on January 9, 2016.

BLOK, Anton. The Mafia of a Sicilian Village: A Study of Violent Peasant Entrepreneurs, 1860-1960. Oxford: Blackwell, 1974.

_-_-- The Peasant and the Brigand: Social Banditry Reconsidered. Comparative Studies in Society and History 14, 1972, p. 495- 504.

BRAND, Tylor. Lives Darkened by Calamity: Enduring the Famine of World War I in Lebanon and Western Syria." Ph.D. diss. Beirut: American University of Beirut, 2014.

BUHEIRI, Marwan. The peasant Revolt of 1858 in Mount Lebanon: Rising Expectations, Economic Malaise and the Incentive to Arm. In: KHALIDI, Tarif (ed.), Land Tenure and Social Transformation in the Middle East. Beirut: American University of Beirut, 1984, p.291-301.

CHAKRABARTY, Dipesh. Provincializing Europe: Postcolonial Thought and Historical Difference. Princeton: Princeton University Press, 2007.

----. Subaltern Studies and Postcolonial Historiography. Neplanta: Views from the South, n. 12000 , p. 9-32.

CHATTERJEE, Partha. The Nation and its Fragments: Colonial and Postcolonial Histories. Princeton: Princeton University Press, 1993.

CHEVALIER, Dominique. La société du Mont Liban à l'époque de la révolution industrielle en Europe. Paris: University of Chicago Press, 1971. . Aux origines des troubles agraires Libanais en 1858. Annales, n. 14, 1959, p. 44-51.

CHIBBER, Vivek. Postcolonial Theory and the Specter of Capital. London, New York: Verso, 2013.

DAVIS, Mike. Late Victorian Holocausts: El Niño Famines and the Making of the Third World. London: Verso, 2001.

FAWWAZ, Leila. An Occasion for War: Civil Conflict in Lebanon and Damascus in 1860. Berkeley and Los Angeles: University of California Press, 1994. 
FERRERAS, Norberto 0. Bandoleiros, cangaceiros e matreiros: revisão da historiografia sobre o Banditismo Social na América Latina. História n. 22, 2, 2003. Accessed online at http://dx.doi.org/10.1590/\$0101-90742003000200012 on August 1, 2016.

FIRRO, Kais. Silk and Agrarian Changes in Lebanon, 1860-1914. International Journal of Middle East Studies, v. 22, n. 2, May 1990, p. 151-69.

GUHA, Ranajit. Dominance Without Hegemony: History and Power in Colonial India. Cambridge and London: Harvard University Press, 1998.

. On Some Aspects of the Historiography of Colonial India. In: (ed.). Subaltern Studies I: Writings on South Asian History \& Society. Delhi: Oxford University Press, 1982, p. 37-44.

HOBSBAWM , Eric J. Bandits. New York: The New York Press, 2000.

; SCOT, Joan Wallach. Political Shoemakers. Past \& Present 89, Nov. 1980, p. 86114.

IRBY, J oseph K. Aspects of Musha Land Tenure in Lebanon. Yearbook of the Association of Pacific Coast Geographers, 33, 1971, p.153-60.

ISSAWI, Charles. Ed. The Economic History of Turkey, 1800-1914. Chicago: University of Chicago Press, 1980.

---- The Economic History of the Middle East, 1800-1914. Chicago and London: University of Chicago Press, 1966.

KERR, Malcolm (ed.). Lebanon in the Last Years of Feudalism, 1840-1860: A Contemporary Account by Antun Dahir al- 'Aqiqi and Other Documents. Beirut: American University of Beirut, 1959.

MAIER, Charles. Leviathan 2.0: Inventing Modern Statehood. Cambridge and London: The Belknap Press of Harvard University Press, 2012.

MAKDISI, Ussama. Corrupting the Sublime Sultanate: The Revolt of Tanyus Shahin in Nineteenth-Century Ottoman Lebanon. Comparative Studies in Society and History, v. 42, n. 1, Jan. 2000, p. 180-208.

MAOZ, Moshe. Communal Conflicts in Ottoman Syria during the Reform Era: The Role of Political and Economic Factors. In: BRAUDE, Benjamin; LEWIS, Bernard (eds.). 
Christians and J ews in the Ottoman Empire: The Functioning of a Plural Society. New York: Holmes and Meier, 1982, p. 91-105.

MUNDI, Martha; SAUM AREZ Richard. Governing Property, Making the Modern State: Law, Administration and Production in Ottoman Syria. London: I.B Tauris, 2007.

MURPHEY, Rhoads. Tobacco Cultivation in Northern Syria and Conditions of its Marketing and Distribution in the Late Eighteenth Century. Turcica, 17, 1985, p. 207-11.

NUJAIM Bulos (M. Jouplain). La Question du Liban: Etude d'histoire diplomatique et de droit international. Paris: Librairie Nouvelle de Droit et de Jurisprudence, 1908.

OWEN, Roger. The Silk-Reeling Industry of Mount Lebanon, 1840-1914: A Study of the Possibilities and Limitations of Factory Production in the Periphery. In: ISLAM OGLUINAN, Huri (ed.). The Ottoman Empire and the World Economy. New York: Cambridge University Press, 2004, p. 271-83.

PORATH, Yehoshua. The Peasant Revolt of 1858-1861 in Kisrawan. Asian and African Studies, 2, 1966, p. 77-157.

QUATAERT, Donald. Social Disintegration and Popular Resistance in the Ottoman Empire, 1881-1908: Reactions to European Economic Penetration. New York and London: New York University Press, 1983.

RIHANI, Ameen. Der Eseltreiber und der Priester. Ursula Assaf and Simon Yussuf Assaf, transl. Geneva: Patmos, 1996; Dusselrof and Zurich: Patmos, 2003; and Mannheim: Patmos, 2011.

. Al-M ukari wa-I-Kahin [The M uleteer and the Priest]. Beirut: Dar al-Rihani li-I-Tiba'a wa-I-Nashr, 1969.

Al-Mukari wa-I-Kahin [The Muleteer and the Priest]. New York: Al-Huda Printing Press, 1904.

SATYA, Laxman D. Cotton and Famine in Berar, 1850- 1900. New Delhi: Manohar, 1997.

SCHÖLCH, Alexander. Was There a Feudal System in Ottoman Lebanon and Palestine? In: KUSHNER, David (ed.). Palestine in the Late Ottoman Period. Jerusalem and Leiden, 1986, p. 130-45.

STRAND, David. Rickshaw Beijing: City People and Politics in the 1920s. Berkeley: Los Angeles and London: University of California Press, 1989. 
THOBIE, Jacques. Intérêts et Impérialisme Français dans l'Empire Ottoman (1895-1914). Paris: Imprimerie Nationale, 1977.

THOMPSON, E. P. Customs in Common: Studies in Traditional Popular Culture. New York: New Press, 1991.

TOKSÖZ, Meltem. The Çukurova: From Nomadic Life to Commercial Agriculture, 18001908. Ph.D .dissertation, State University of New York at Binghamton, 2000.

UNITED KINGDOM. HOUSE OF COMMONS. Report for the Year 1886 on the Trade of Beyrout. In: Sessional Papers, 1887. London: William Clowes and Sons, for HMSO, 1806-1908, p. 503-10.

VERNEY, Noël; DAM BMANN, George. Les Puissances Etrangères dans le Levant en Syrie et en Palestine. Paris: Guillaumin, 1900.

WELIVER, Phyllis. Oscar Wilde, Music, and the 'Opium-Tainted Cigarette': Disinterested Dandies and Critical Play. Journal of Victorian Culture, 15, 3, 2010, p. 315- 47.

WEULERSSE, Jacques. Paysans de la Syrie et du Proche Orient. Paris: Gallimard, 1946.

YAZBAK, Yusuf Ibrahim. Al-Judhur al-tarikhiyya li al-harb al-lubnaniyya [The Historical Root Causes of the Lebanese War]. Beirut: Nawfal, 1993. 